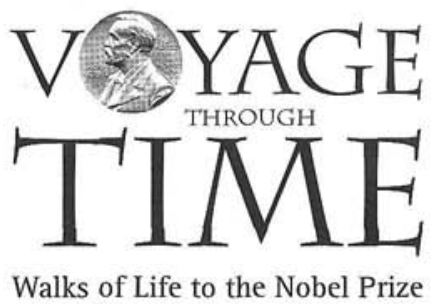


This page is intentionally left blank 


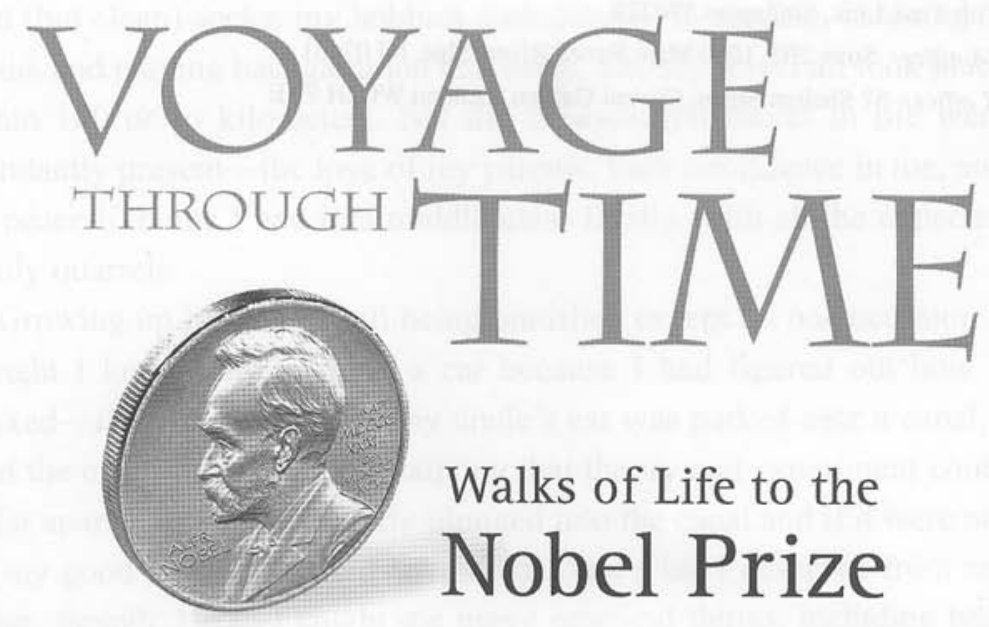

AHMED ZEWAIL

Linus Pauling Chair Professorship

California Institute of Technology, USA 
Published by

World Scientific Publishing Co. Pte. Ltd.

5 Toh Tuck Link, Singapore 596224

USA office: Suite 202, 1060 Main Street, River Edge, NJ 07661

UK office: 57 Shelton Street, Covent Garden, London WC2H 9HE

\section{VOYAGE THROUGH TIME \\ Walks of Life to the Nobel Prize}

Copyright $\odot 2002$ The American University in Cairo Press

This edition is published by arrangement with

The American University in Cairo Press

All rights reserved.

ISBN 981-238-340-9 (pbk)

Printed in Singapore. 


\section{To Egypt}

You lit the beacon of civilization

You deserve a brilliant future

May my voyage light a candle of hope for your youth 
This page is intentionally left blank 


\section{Contents}

List of Illustrations $\quad i x$

Prologue 1

First Steps

On the Banks of the Nile $\quad 11$

D) The Gate to Science

$\begin{array}{ll}\text { The Alexandria Years } & 27\end{array}$

2 The American Encounter

Independence in Philadelphia 51

California Gold

From Berkeley to Pasadena

73

The Invisible Atom

Close-up at Caltech 99 
The Race against Time

Six Millennia to Femtotime

Time and Matter

The Femtouniverse in Perspective

On the Road to Stockholm

Festivities and Fairy Tales

Q A Personal Vision:

The World of the Have-Nots

$10 \begin{aligned} & \text { Walks to the Future } \\ & \text { My Hope for Egypt and America }\end{aligned}$
.

Epilogue

Success-Is There a Formula?

Further Readings

Appendix

Index 


\section{Illustrations}

Between pages 84 and 85

At the age of twelve

My mother, Rawhia Dar

My father, Hassan Zewail

My father and I on the beach in Alexandria

My sisters Seham and Nana and I in Desuq's club

My mother and I on a visit to the Pyramids in 1988

Uncle Rizq

My letter from President Nasser

Umm Kulthum

Downtown Damanhur, the city of my birth

A vegetable market in Damanhur today

Sidi Ibrahim mosque in Desuq in 1998

My art and painting group at preparatory school

Outside our secondary school in 1961, with several of my friends 
The G-7 specials in chemistry in 1966

The staircase of the Faculty of Sciences of the University of Alexandria

During a university trip to Upper Egypt in 1966

As a $m u^{\prime}$ 'id in 1968 with students of the Faculty of Science

Dr. Yehia El-Tantawy

Dr. Samir El-Ezaby

A group of $m u$ ' $i d$ s with professor Rafat Issa

My landlady and I in Alexandria in 1969

Letter of acceptance from the University of Pennsylvania

With Dr. 'Abd al-Rahman El-Sadr, Nico Bloembergen, and George Porter in Alexandria in 1983

The participants in the International Conference on Photochemistry and Photobiology at the Giza Plateau, 1983

In the laboratory at Penn with John Wessel in 1970

Robin Hochstrasser at the blackboard

At the wedding of John Wessel

Graduation day at Penn, 1973

In the hall where I received the Franklin award in 1998

Charles Harris and Amani at UCB in 1997

On the occasion of receiving an honorary doctoral degree from the University of Pennsylvania

My "faculty position decision" table

The faculty of Caltech's Division of Chemistry and Chemical

Engineering at the birthday celebration for Linus Pauling, 1986

Our first laser laboràtory at Caltech, with Tom Orlowski

The first lab for a picosecond laser at Caltech, with Dan Dawson and Rajiv Shah 
Between pages 148 and 149

Receiving the award from the king, Stockholm, December 10, 1999

The banquet arrangement at the city hall in Stockholm, December 10, 1999

The Nobel awards ceremony of 1999

Dema and I meet King Gustav and Queen Silvia of Sweden

Giving the Nobel banquet address, December 10, 1999

My family, dressed for the evening's big event

The Nobel medal

The design by artist Nils G. Stenqvist on the inside of the Nobel diploma

The Grand Collar of the Nile

At the presidential palace

With President Mubarak on the occasion of the receipt of the Grand Collar of the Nile, December 16, 1999

Postage stamps issued on the occasion of the Franklin prize in 1998, and the Nobel prize in 1999

With President Clinton, January, 2000

With Pope John Paul II, November, 2000

With the laser setup in the laboratory

An artist's rendering of the femtoscope capturing atoms in motion

The Nobel poster- decisive moments in the life of molecules

Two views of the femtoscope apparatus

Stop-motion photographs of the falling cat

Freezing time: six millennia of history to the femtosecond

A boll of Egyptian cotton

A modern Greek ten-drachma coin showing Democritus and the atom

Galileo Galilei

A quiet moment with my family in Pasadena 
Between pages 212 and 213

Maha's graduation from Caltech, 1994

Amani's graduation from San Marino High School in 1997

Halloween trick or treating with my sons

Dema Faham on the occasion of the awarding of the King Faisal International Prize in March of 1989

Wedding photo of Dema and me, with family, at Caltech's Athenaeum, 1989

Professor Bengt Nordén introducing me at the Nobel awards ceremony

My family and friends at a reception in Stockholm

With Naguib Mahfouz in Cairo, 2000

Dema and I with Nabeel and Hani

Nabeel and Hani, demonstrating their fishing skills in Cairo

Omar Batisha and I at al-Fishawi cafe in Cairo in 1997

My family on board a yacht on the Nile, December, 1999

In the Tea Garden of the Semiramis

With Mme. Amal Fahmy in West Lost Angeles, 1988

Walking with Linus Pauling on the Caltech campus

Dick Bernstein and I sharing coffee and points of view in 1987

Street scene in Desuq at the dedication of a street in my name in 1998

At the head of the street named for me in Damanhur, 1998

Dr. Ahmed Zewail Square in Alexandria

My wife and I, with Nabeel and Hani, at the Zewail Square open museum wall in Alexandria

The souvenir photograph taken at the Athenaeum, January, 2000

Groundbreaking ceremony for the University of Science and

Technology on January 1, 2000 


\title{
Prologue
}

\begin{abstract}
telephone call at dawn on October 12, 1999, shook my inner being just as an earthquake does in California. In Pasadena, 1 California, I received the news at 5:30 A.M. from the secretarygeneral of the Swedish Academy of Sciences, congratulating me on the award of the 1999 Nobel Prize in Chemistry. He read the citation of the academy and indicated that I was receiving the prize unshared. After three other members of the academy praised the contribution for which the prize was awarded, the secretary-general came back on the line and said: "In twenty minutes we will be announcing it to the world-these are the last twenty minutes of peace in your life." The secretary-general was right. My life has changed, and in the years to come there will be opportunities to reflect on these changes following the Nobel prize.

The award was for research on atoms and molecules, which have an enormously complex "sociology." Ever since their discovery, scientists have been concerned with their behavior in matter-why atoms and molecules sometimes like or attract each other and sometimes don't. This love and hate dynamic is extremely important-it determines why substances exist in different shapes and phases, and how they transform
\end{abstract}


to other substances. And, like humans, the only way to find out how they behave is to watch them in action. However, the entire time span of the journey during any transformation is a billion trillion times shorter than the human lifespan. That is why for twenty-four centuries, since its conception, the atom's motion in real time was invisible.

For atoms and molecules, the scale of time involved is awesome-its unit is the femtosecond. A femtosecond is a millionth of a billionth of a second, a quadrillionth of a second; it is one second divided by ten raised to the power of fifteen $\left(10^{-15}\right)$, or 0.000000000000001 second. Put in comparative terms, a femtosecond is to a second as a second is to $32 \mathrm{mil}-$ lion years. In one second, light travels about 186,000 miles $(300,000$ kilometers), almost from here to the moon; in one femtosecond, light travels 300 nanometers ( 0.0000003 meter), the dimension of a bacterium, or a small fraction of the thickness of a human hair. With femtosecond timing, the atom's motion becomes visible.

The call from Stockholm was for our contribution to the science of time and matter - the development, with laser strobes, of femtosecond timing techniques, making possible the observation of matter's dynamics with atomic-scale resolution. With the shutter speed of the "camera" more than one million million times faster than a normal one, we can now freeze the motion of atoms and resolve the transition states in the journey of molecular reactions. The discovery of phenomena and the development of concepts allow us to understand the behavior and the forces in this microuniverse of atoms and molecules, with the prospect of taming matter. The new field of science was named femtochemistry, and the coining of this word was appropriate-it captured the interconnection between the time scale (femtosecond) and the molecular change (chemistry). By this ideal marriage between time and matter, femtochemistry ends the race against time for all molecules of nature, including those of life.

At exactly 6:00 A.M. Pacific Standard Time the prize announcement was posted on the Internet, and, concurrently at 3:00 P.M. Stockholm time, the Academy held a press conference. My family and I saw the press release on the Internet on our home computer and read the citation, which says, in part: 
This year's laureate in Chemistry is being rewarded for his pioneering investigation of fundamental chemical reactions, using ultra-short laser flashes. . . . Professor Zewail's contributions have brought about a revolution in chemistry and adjacent sciences. ... Zewail's technique uses laser flashes of such short duration that we are down to the time scale on which the reactions actually happenfemtoseconds (fs). . . . We can now see the movements of individual atoms as we imagine them. They are no longer invisible. ... With the world's fastest camera available, only the imagination sets bounds for new problems to tackle.

At the ceremony that followed two months later, Professor Bengt Nordén, a member of the Nobel Committee, introduced me with more descriptive words:

Zewail's use of the fast laser technique can be likened to Galileo's use of his telescope, which he directed towards everything that lit up the vault of heaven. Zewail tried his femtosecond laser on literally everything that moved in the world of molecules. He turned his telescope towards the frontiers of science.

The Nobel recognition of scientific achievements is the highest honor for any scientist, but for me this recognition adds a new dimension-it represents pride in the world from which I came. The 1999 Nobel Prize in Chemistry was the first in chemistry, physics, or physiology or medicine that Egypt and the Arab world can claim. Egypt has had a Nobel Prize for Peace, awarded to President M. Anwar al-Sadat, and a Nobel Prize in Literature, awarded to the renowned novelist Naguib Mahfouz. However, in the sciences, over the past one hundred years of the exis- 
tence of the prizes, the Islamic world-which represents more than one billion of the Earth's six billion in population-can claim only Abdus Salam from Pakistan, cowinner of the 1979 Nobel Prize in Physics, and myself. Nearly all of the prizes in science and medicine have been awarded to the Western world.

If the Nobel prizes had existed 6,000 years ago, when Egypt's civilization began, or even 2,000 years ago, when the famous Library at Alexandria was established, Egypt would have garnered many of them in the scientific fields. A millennium ago, the Arab and Islamic civilization, which made major, seeding contributions to the European Renaissance and to science and literature, would surely have had an equally large share on account of the work of many scholars, such as Avicenna (Ibn Sina), Averroës (Ibn Rushd), Geber (Jabir Ibn Hayyan), Alhazen (Ibn al-Haytham), and others.

The situation is different today, and one can understand why the announcement of my Nobel Prize in Chemistry made millions of Arabs and, I believe, the developing world at large more hopeful about the future and more confident in their people's ability to achieve noteworthy advances in science, the hallmark of the Western world. These sentiments were evidenced in the thousands of messages I received over the days that followed. The Egyptians were full of joy. President Mubarak called me at home, and in December I received from the president the highest state honor, the Grand Collar of the Nile. The hope is that this first science prize will inspire younger generations to think positively and for governments to develop new programs for science and technology.

At Caltech (the California Institute of Technology) the news was welcomed with much appreciation. Caltech had already had twentyseven Nobel prizes credited to its faculty and alumni, but every new one merits gala celebrations as it reaffirms Caltech's preeminence in science and its contributions through science to the betterment of humankindthis also adds to Caltech's fame. There were many parties, and one was held at the Athenaeum, our faculty club, with about five hundred persons present. This grand gathering was scheduled after my visit to the White 
House in Washington, D.C., and after the award ceremony in Stockholm. In the evening at the Athenaeum, I spoke of the greatness of the place that allowed our team to make the scientific contributions cited by the Nobel committee only ten years after my arrival on campus as a beginning assistant professor, but I didn't forget to speak about my plans for the future.

For this journey on the road to the Nobel prize, I have been asked several times to write a biography, or at least a biographical summary of my life. I declined these invitations. I was of the opinion that a traditional biography should represent a lifetime of work and experience and much effort and time are needed to do it well. In July of 1997 while on a trip to Cairo this strong feeling softened to a more moderate one. I was stimulated to ask a few questions by two books I was reading, one titled $A$ History of Knowledge by Charles van Doren and the other Making Waves by Charles Townes. How did I acquire knowledge? Why did I become a scientist? What are the forces that have determined the walks of my own life? What are the meanings of faith, destiny, and luck? In the attempt to answer such complex questions, I began to sketch my thoughts.

I was sitting in the Tea Garden of the Semiramis Intercontinental Hotel, in the grip of the fantastic panorama of the Nile. On its banks, three major epochs of Egypt's history seemed symbolized: a pharaonic obelisk, a minaret of a mosque, and the giant modern postrevolutionary structures of the Cairo Tower and Opera House. Scanning the landscape unfolded events of the past, bringing back memories and reflections on the history of the land, the eternity of the Nile, and my transition to the land of opportunity in America. I decided to write, thinking it would be a few pages long. I ended up filling eight notebooks (made of papyrus!) in a few days, and for some reason the pen would not stop. In fact, one of my secretaries, Jeanne, noted that what I wrote was not a draft-it was written with few corrections. In the background, the music of Umm Kulthum, the great singer of Egypt, kept me going.

This book, in its ten chapters, describes my journey from Egypt to America; it is a voyage through time. I use "walks of life" purposely as a term to reflect the apparently random nature of walks and the incidents 
and surprises that may change such walks to define one's path through life. The book encapsulates six stations of the journey: childhood, which began on the banks of the Nile and was shaped by the love and confidence of my parents; admission to the Faculty of Science in Alexandria, which defined my science career as well as my engagement to a science student; the scholarship in America, which opened up a whole new world for me; the years of scientific discovery at Caltech, which have changed the way we think about the science of time and matter; the receipt of the King Faisal International Prize, which was the first major prize to recognize my group's contribution and which ultimately provided me with a new family; and the receipt of the Nobel prize, which led to a place in the history of science.

The book focuses not only on my walks of life. It is also about time and matter. It gives an exposition of the scientific development and the path to discovery in the femtouniverse. It ends with my concerns about the new world disorder and with hopes for the future, with focus on Egypt and America. As such, the book highlights three elements: life, science, and vision. Chapters one through four recount stations of my life; chapters five through seven overview the scientific work; and chapters nine and ten present a personal perspective on the prospect for world order through science and on my wish for the two cultures that I share. Chapter eight is special in that it describes the festivities and "fairy tales" that were happy moments for my family; some details about awards are included more for those not familiar with the prize culture of science.

Throughout the book, I emphasize the human dimension of my experience and the many walks that led to the appearance of a defined path on this landscape of the voyage. I found that faith, destiny, serendipity, and intuition were forces influencing this complex path. Perhaps one of the most valuable gifts for scientists (and artists) is to have intuition or insight, the direct knowing or learning of something without the conscious use of reason. Faith can provide strength and guides people toward ethical and moral behavior, unless it is wrongly exploited. In Islam, the faith of about one sixth of the world's population, the real message is clearly and unequivocally expressed in the 
Holy Quran. Islam and other religions provide high standards for the life of their adherents and success becomes an integral part of the betterment of humankind.

Many might think that one can orchestrate success only with endowed intelligence or genius. In my case, I did not walk the course of my life easily - there were many challenges and obstacles. From the beginning, though, I knew the strength of passion for my work. I also knew that I am an optimist and perhaps endowed with the good genes that brighten insights. American journalists frequently ask how I could rise to such heights of success in spite of what they perceive to have been a restricted and resourceless environment. My birth in Egypt was not an obstacle to my achievement, and my life's path would not necessarily have been any easier had I grown up in any other country. Egypt planted the seeds properly and America gave me the opportunity.

I came to America for my Ph.D. education and to have a taste of science at the frontiers. Struggling to learn the English language and to overcome scientific, cultural, and political barriers, I never thought that I could one day be a faculty member at Caltech, one of America's premier universities. After being at Caltech, a science village full of giants, I didn't expect, as an assistant professor, that one day I would be honored with the Linus Pauling Chair, named after the winner of two Nobel prizes. Caltech is truly unique and I have been fortunate to have begun my scientific journey at this institution.

It is my hope that in this book the reader will find that the saga told here reflects the human experience of a person who was born, educated, and worked not only in the right place at the right time but also with passion and optimism. I also hope that through the knowledge of how discoveries are made and of what it takes to contribute to world science, this book will inspire young people to gain confidence and to feel that it is possible! As Sir Humphrey Davy eloquently said in 1825: "Fortunately, science, like that nature to which it belongs, is neither limited by time nor by space. It belongs to the world, and is of no country and of no age."

With this in mind, my goal here is to address the general public of 
both the developing and the developed world, and not specifically the specialist or select intellectuals. Most intellectuals and scientists do not like to give personal details or discuss their own achievements-it is considered poor taste. I follow this tradition in my professional practice and in my office-my awards are in my desk drawers! But here I follow a different route. I take the opportunity to describe the path to discovery, to popularize the science and its beauty, and to be explicit about the human dimension. Throughout, I mention some discoveries and contributions and the scientists behind them, and, in the hope of stimulating young people, I also mention the crowning of these achievements by the Nobel and other prizes. Naturally, I cannot list all players as this book is not intended for such a purpose.

This book would not have been completed without the support of a great many people. Although the subjects covered are in large part based on my science work, public lectures, and other writings, the final product came about as a result of the enthusiastic overtures of Mark Linz, the Director of the AUC Press, with whom I had many wonderful and persuasive discussions. The Press also provided me with a gifted editor, Mary Knight, who, through "oral history" sessions, has managed to kindle my interest in completing the work. I am grateful to Mary for her devotion and genuine interest to produce a high-quality book. I am also thankful to other members of the AUC Press staff, especially Neil Hewison, the Managing Editor, for his care and thoroughness, and Andrea El-Akshar for her careful and elegant design. In preparing the text, my office assistants went through several draft versions, and I wish to thank them all: Janet Davis, Sylvie Gertmenian, and Mary Sexton, and toward the end, Karen Hurst.

The science story would not have been told without the teamwork effort of members of my research group, past and present, at Caltech. I hope that they will find this saga reflects the exciting time of discovery and their days in Femtoland. Science and nonscience friends have been a continuous source of support and encouragement and to them I 
owe a debt of gratitude. Over the years, many have given their unqualified support. I wish to thank Spencer Baskin of Caltech and Hesham El Ashmawy in Cairo for their special care over the past few years.

Last but not least, my family has always been the source of love and enjoyment in my life. To them I owe more than words can describe. In my immediate family, my wife, Dema, has made my work possible by her understanding of my passion and by her critical support. Forever I am grateful. My daughters, Maha and Amani, and my sons, Nabeel and Hani, have given life a real joy, and with their happiness and success surely the mind can be free to write our story that I told here. 